\title{
Canavan Disease and Recent Advances
}

\author{
Mehmet Alp Dirik' (D), Burcin Sanlidag² (D), Eray Dirik² (D), Nail Bulakbaşı' (D) \\ 'Department of Radiology, Dr. Suat Günsel University Faculty of Medicine, Kyrenia, North Cyprus \\ ${ }^{2}$ Division of Pediatric Neurology, Department of Pediatrics, Near East University Faculty of Medicine, Nicosia, North Cyprus
}

ORCID iDs of the authors: M.A.D. 0000-000I-9427-282I; B.S. 0000-0003-I0II-475X; E.D. 0000-0002-4429-6478; N.B. 0000-000I-7528-8I07.

Cite this article as: Dirik MA, Sanlidag B, Dirik E, Bulakbaşı N. Canavan Disease and Recent Advances. Cyprus J Med Sci. 2021 ; 6(3): $273-278$.

Canavan disease (CD) is a rare autosomal recessively inherited leukodystrophy. The genetic defect related to the aspartoacylase gene. The clinical characteristics of CD include hypotonia, macrocephaly, developmental delay, and visual impairment within the first year of life. There is currently no cure for CD, however, new therapeutic modalities and gene therapy options are under investigation. Possible mechanisms in the pathogenesis include astrocytic edema caused by $\mathrm{N}$-acetyl-L-aspartic acid (NAA) serving as a water pump and diminished acetate that is required for myelin synthesis. The current diagnostic approach to identify CD cases includes the demonstration of increased urinary NAA level, diminished or absence of enzyme activity in cultured skin fibroblasts, the loss of white matter including U-fibers in magnetic resonance (MR) imaging, NAA peak in MR spectroscopy (MRS), and genetic testing, in which more than 70 mutations have been identified. Among these diagnostic approaches, the NAA peak detected with the use of MRS is highly characteristic of $C D$ and is the cornerstone in early diagnosis.

Keywords: Canavan disease, diagnosis, neuroimaging, genetic, treatment

\section{INTRODUCTION}

Canavan disease (CD) is a rare, autosomal recessive leukodystrophy that is characterized by spongy degeneration of the white matter of the brain.' Degenerating white matter is replaced by fluid that is named as vacuolating myelinopathy. ${ }^{2}$ CD is caused by a defect in the aspartoacylase (ASPA) gene, encoding the enzyme aspartoachylase, which has a role in hydrolyzing $\mathrm{N}$-acetyl-L-aspartic acid (NAA) and provides an acetyl group to oligodendrocytes for myelin synthesis. $^{3-6}$ A defect in aspartoachylase results in diminished myelin biosynthesis, dysmyelination, and brain edema. ${ }^{7}$ Although CD is prevalent among the Ashkenazi Jewish population, it also has an incidence of 1:200,000-l:400,000 among the non-Jewish population. The mutation responsible for CD among the two populations may differ. ${ }^{8}$

\section{MECHANISM OF CD}

NAA found only in neurons. ${ }^{8}$ NAA and NAA related dipeptide N-acetyl-aspartyl-glutamate (NAAG) is transported from the cytoplasm to the extracellular space after synthesis within the neuron. Then NAA is taken up by oligodendrocytes using a dicarboxylic acid transporter and hydrolyzed by ASPA to aspartate and acetate. Acetates are then used in the synthesis of fatty acids, and they are used for the production of myelin lipids.?

Decreased levels of NAA have been reported in many other neurodegenerative disorders, but elevated NAA is characteristic of $C D$. The exact pathophysiologic mechanism causing white matter degeneration in the case of increased NAA is yet unknown. Several hypotheses, however, have been established for possible pathophysiology.

CD is characterized by an increase in NAA in addition to a decrease in acetate and myelination. ${ }^{10-12}$ The loss of function of ASPA causes a reduction in free acetate, while NAA is essential for the synthesis of myelin lipids that is crucial for myelination in the central nervous system (CNS), particularly during the postnatal period. ${ }^{10}$ Impaired lipogenesis was postulated to be the reason for spongiform degeneration in $C D .^{13,14}$ In an ASPA knockout mice model, polar and nonpolar lipid levels that are crucial for myelin synthesis were found to be lower when compared to the control group. ${ }^{13}$ Cerebroside and sulfatide reduction has also been reported in human and the rat CD model. Although a reduction in the lipids level has been demonstrated, it may not have a direct relation with the severity of the disease, indicating that deficiency of acetate may not be the only underlying pathology of CD.? 
NAA was suspected to serve as a water pump removing metabolic water from the mitochondria of neurons. Accumulation of NAA results in astrocytic edema and formation of vacuoles. ${ }^{15}$ In contrast, NAA was shown to be nontoxic even at high concentrations. No changes were detected in NAA levels in $C D$ mice models following the introduction of the entire ASPA gene. 16,17 Aquaporin (AQP) 4 is a water transporter and is the principal member of the AQP family in the CNS, which is expressed by astrocytes. ${ }^{15,18,19}$ Clarner et al. ${ }^{20}$ demonstrated that AQP4 was present throughout the cytoplasm in the CD mice model and was located only in astrocytic end-feet in control mice. AQP4 was thought to be a new therapeutic target for partial prevention of spongy degeneration through the regulation of astroglial water homeostasis.

It has been demonstrated that the elevation of oxidative stress markers can cause the loss of oligodendrocytes and demyelination in the first few days after birth, and in turn, NAA was thought to have a role in the metabolic integrity of oligodendrocytes. ${ }^{2 !}$

Additionally, nucleosomal histones are components of chromatin, and their function is modulated by acetylation. A decrease in acetate may disturb the expression of genes involved in the maturation of oligodendrocytes. ${ }^{22}$ Previous findings do suggest that immature oligodendrocytes have higher NAA levels than mature oligodendrocytes or astrocytes. It indicates the importance of the function of ASPA in immature oligodendrocytes. ${ }^{23}$ ASPA plays an important role in the maturation of oligodendrocytes and also contributes to the pathophysiology of CD. ${ }^{24}$

Conversely, NAA may affect NMDA receptors in oligodendrocytes resulting in demyelination. The effect of NAA or NAAG on the oligodendrocytes' NMDA receptor is probably not a major contributor to white matter damage. ${ }^{25}$

\section{THE CLINICAL COURSE OF CD}

Symptoms usually emerge after a period of normal development, which occurs during the first few months of life, a rapid course of progression of CD then occurs. The major symptoms of $C D$ include hypotonia, macrocephaly, feeding difficulties, developmental delay, and visual impairment. ${ }^{26-28}$ Macrocephaly becomes evident after birth, usually during the first year of life. 9,26 The classical triad of the infantile CD in early childhood is hypotonia, macrocephaly, and head lag. 9 There are, however, a few cases that also report normocephaly or microcephaly. ${ }^{29-32}$ Ataxia, poor sucking, and intellectual disabilities have also been reported in CD patients.

In the later stages of the disease, patients develop optic atrophy and spasticity. They usually become highly debilitated

\section{Main Points}

- Canavan disease (CD) is a rare genetically inherited disorder that is characterized by hypotonia, macrocephaly, developmental delay and visual impairment within first year of life.

- The NAA peak detected in MRS is highly characteristic of $C D$ and important in early diagnosis.

- Although more than 70 mutations had been described, genetic testing anables genetic consultation. including the loss of ambulation, difficulty in swallowing, and seizures. A long term prognosis is still poor in infantile $C D$, and patients are unlikely to survive beyond adolescence. Some patients with milder forms may survive beyond the second decade of life.?

The onset of mild/juvenile CD often begins after 5 years of age. It is characterized by a mild developmental delay of speech and motor skills, developmental delays may also be nonspecific, and may not be immediately recognized. ${ }^{33,34}$ The adult-onset of symptoms may resemble symptoms associated with the condition of multiple sclerosis. ${ }^{33}$ In addition, severe retinal degeneration had also been reported in a patient with CD. ${ }^{35}$

\section{DIAGNOSTIC TESTS FOR CD Laboratory Tests}

Diagnosis is based on neurological findings, laboratory tests, cultured skin fibroblasts, neuroimaging, and genetic testing collectively.

Laboratory findings, neuroimaging, and genetic testing are crucial to distinguish CD from other neurodegenerative disorders.

Serum and urine NAA levels are elevated in patients with CD. Excessive urinary NAA excretion was found to be almost 200 times higher than the amounts found in normal age-matched individuals or obligate carriers. ${ }^{36}$

In a study including 17 CD patients, one patient had elevated serum NAA levels while another six patients had high urine NAA concentrations. In 10 CD patients of an infantile group, neither serum nor urine samples had elevated NAA levels. ${ }^{37}$ Additionally, the urine concentrations of NAA and the severity of their symptoms did not correlate in two siblings with $C D$. Therefore, urinary NAA excretion levels may not be completely reliable criteria for the diagnosis of $C D$.

Cultured skin fibroblasts can be used to asses ASPA enzyme activity. It can demonstrate low enzyme activity even in the absence of a known ASPA gene mutation; however, it may not be reliable because the activity may vary with culture conditions. ${ }^{10,34,38}$ Aspartoachylase enzyme production is very low in normal amniocytes and chorionic villi, which makes the detection of this enzyme unreliable in prenatal diagnosis. ${ }^{39}$

\section{Neuroimaging}

The MRI of the brain in CD patients demonstrates macrocephaly and a diffuse loss of white matter including subcortical U-fibers and usually bilateral globus pallidus and thalamus involvement. Putamen and caudate nucleus are spared, which is very typical for $C D$. Cerebellum and brain stem tracts may also be affected. ${ }^{2,40-43}$ Rarely multiple rounds or oval cystic changes can be observed in white matter causing a honeycomb appearance. ${ }^{44}$ In infantile $C D$, before characteristic findings emerge, cytotoxic edema with restricted diffusion on brain MRI may be observed. ${ }^{45}$ Multiple small cysts in white matter predominantly in the posterior regions causing spongy appearance in infantile CD patients have also been reported. ${ }^{46}$

In the case of mild/juvenile CD brain, MRI does not display general white matter disease, instead of increased signal intensities in the basal ganglia have been demonstrated in many children with mild/juvenile $C D .^{47-49}$ A case report of juvenile 


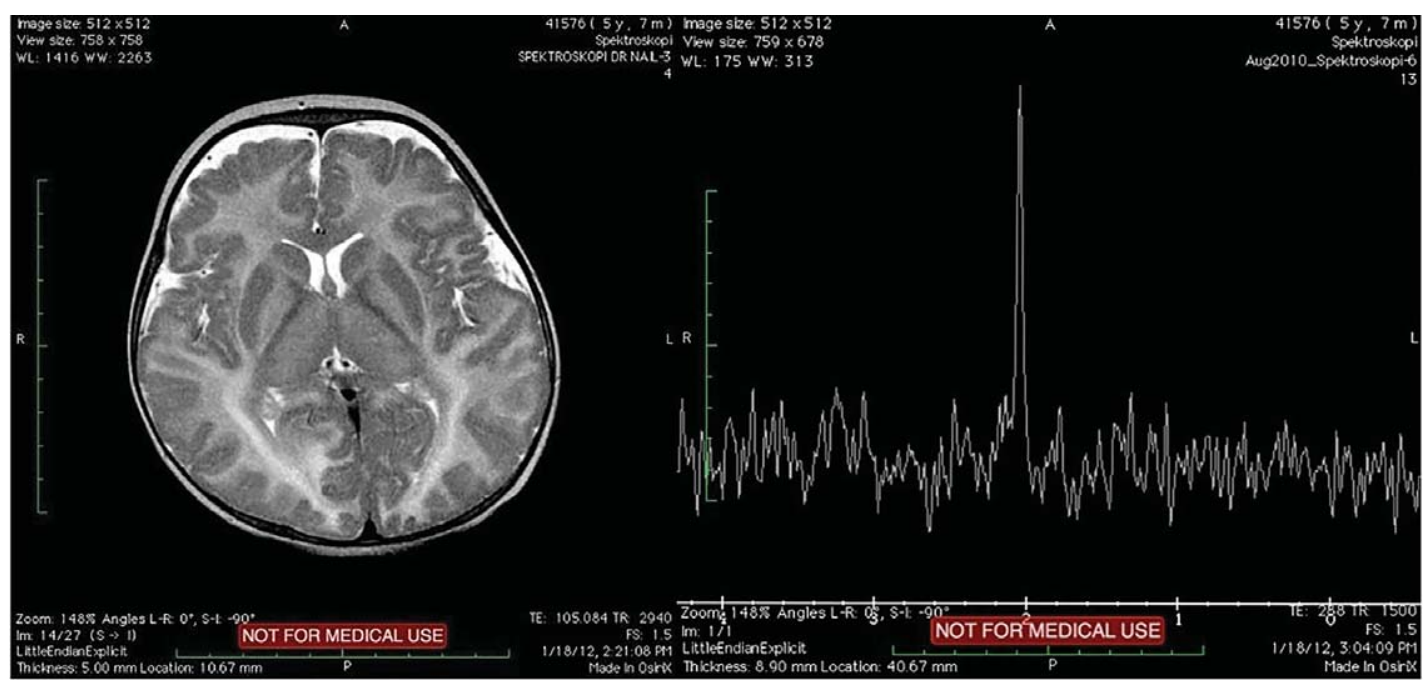

FIGURE I. MRI demonstrating delayed myelinization at corpus collosum, capsula interna genu, and posterior limb. Hyperintensity of both globus pallidus, thalamus, dorsal aspect of brain stem, corticospinal tractus, and cerebellum. MRS demonstrating a prominent NAA (N-aspartyl aspartate) peak on posterior deep white matter lobe.

$C D$ had been reported with distinct pons involvement in addition to caudate nucleus and basal ganglia without white matter involvement. ${ }^{50}$ In another case report with mild clinical presentation, diffuse cortical abnormality without significant white matter involvement had been reported. ${ }^{51}$ Similar changes have also been described in individuals with mitochondrial diseases. $^{47,52}$

MR spectroscopy (MRS) reveals marked elevations of the NAA, which is characteristic of CD. Low choline (Cho)/creatine $(\mathrm{Cr})$ ratio, high myoinositol $(\mathrm{ml}) / \mathrm{Cr}$ ratio, and high lactate levels have also been observed in some CD patients. ${ }^{41}$ Diffusionweighted has demonstrated restricted diffusion with low apparent diffusion coefficient (ADC) values in the early stages of the disease probably due to myelin vacuolation, whereas increased diffusion and high ADC values are demonstrated in later stages of the disease. 41,42

An example of MRI and MRS of a patient with CD is shown in Figure 1. ${ }^{3 l}$ Elevation of NAA in the brain can be detected by MRS before detecting an increase in the levels of NAA in the urine, therefore making MRS a favorable early diagnostic tool for $C D{ }^{53}$

\section{Genetic Testing}

Genetic testing is not only important for the diagnosis of $C D$ but also critical for genetic counseling and prenatal testing. The ASPA gene is located on the short arm of chromosome 17 at 17p/3.2 location with an autosomal recessive inheritance (OMIM 27I900). ${ }^{54}$ More than 70 mutations have been described to be associated with the ASPA gene thus far. ${ }^{3}$ Sistermans et al. ${ }^{55}$ reported that two mutations account for about $98 \%$ of the alleles of Ashkenazi Jewish patients known as E285A and Y23IX. In non-Jewish patients of European origin, the A305E mutation accounts for $50 \%$ of alleles.

Patients with mild/juvenile CD are usually heterozygous with one mild variant and one severe variant with residual ASPA activity. $47,51,56$
A correlation among clinical presentation, enzyme activity, and genotype for CD had been reported by Mendes et al. ${ }^{57}$

\section{DIFFERENTIAL DIAGNOSIS OF CANAVAN DISEASE}

Differential diagnosis of CD includes other neurodegenerative disorders that are associated with a normal or large head circumference. Alexander disease, Tay-Sachs Disease, Metachromatic Lecodystrophy, and Glutaric acidemia type I may be examples of differential diagnosis of CD. Also, viral infections, mitochondrial disorders, particularly Leigh syndrome, and metabolic disorders such as nonketotic hyperglycinemia can cause spongy degeneration of the brain. Cases of mild/juvenile CD may, therefore, be misdiagnosed as a mitochondrial disorder. $^{34}$

\section{GENETIC COUNSELING}

After identification of the pathogenic variant, high-risk relatives are recommended to be tested. If a specific variant is not known, prenatal diagnosis is based on the measurements of NAA in amniotic fluid. ${ }^{34}$ The frequency of carriers among Ashkenazi Jewish populations ranges from 1:37 to 1:40. Population screening is recommended for Ashkenazi Jewish individuals. ${ }^{58}$

\section{Treatment}

There is no specific treatment for $C D$, and the available treatment is designed to increase the patients' quality of life. Adequate nutrition, hydration, and control of seizures with anticonvulsants are recommended. Acetazolamide was demonstrated to be beneficial by reducing intracranial pressure. ${ }^{59}$

However, new therapeutic approaches are under investigation.

\section{CLINICAL TRIALS}

Lithium citrate decreases NAA in the brain of patients with CD and rat models. The introduction of lithium citrate supplied better scores in gross motor function without statistical significance and parental reports of improvement in alertness and visual tracking when compared to baseline. ${ }^{60,61}$ 
Glycerily triacetate treatment has been shown to increase acetate levels in the brain of rats; however, the same treatment did not demonstrate any improvement in patients with $C D$. As it has no significant side effect or toxicity, this drug is now being used in patients with CD. Early intervention of treatment was postulated to be important. ${ }^{62,63}$

Topiramate has been reported to decline head growth velocity in two subjects with CD. ${ }^{64}$

\section{EXPERIMENTAL REPORTS}

NAA, calcium acetate, ethanol, lipoic acid, lithium chloride, pyrazole and derivatives, sodium valproate, and triheptanoin showed different results. They are candidates for future trials. ${ }^{65}$

In a recent mice study, a prolonged survival had been demonstrated in a cell-based therapy using induced pluripotent stem cells-derived neural progenitor cell and oligodendrocytes progenitor cells. ${ }^{66}$

\section{GENE THERAPY}

Gene therapy aims to increase ASPA activity by insertion of the ASPA gene. In mice and CD patients that have received gene therapy treatment, demonstrated an increase in ASPA production and activity. ${ }^{67,68}$ In turn, there was a reduction of NAA levels in CNS and improved spongy degeneration in some cases. $^{69,70}$ However, those changes were transient in some of the cases ${ }^{70}$ and confined to just a local area of the intracerebral injection site. ${ }^{71,72}$ In an animal study, motor defects that were improved have shown to relapse in the later stages of life. ${ }^{69}$

In a recent study, there has been a breakthrough in the treatment of murine CD using a novel gene therapy approach. Although many studies focus on oligodendrocytes, astrocytes were hypothesized to be the origin of spongiform leucodystrophy in CD patients. The wild type gene had been inserted into astrocytes in that study. ${ }^{73,74}$

Clinical applications of gene therapies were done by adenovirus-associated virus (AAV). ${ }^{75}$ Additionally, neuroinflammatory responses after CNS-targeted delivery of AAVmediated gene therapy are a critical concern to establish the immune suppressive strategies, clinical protocols, and so on. ${ }^{76}$

\section{CONCLUSION}

The infantile CD is one of the poor prognostic neurodegenerative disorders. It starts within the first year of life. There is no curative treatment available; however, new therapeutic approaches including gene therapy are under investigation. MR and MRS are noninvasive primary tests that can demonstrate specific findings. Additionally, genetic testing is useful for both definite diagnosis and genetic counseling. The demonstration of the absence or diminished enzyme activity becomes important in cases with no known mutations. Early diagnosis is important for the early implementation of available treatment options in addition to genetic counseling.

\section{Informed Consent: N/A.}

Peer-review: Externally peer-reviewed.

Author Contributions: Concept - B.S., M.A.D.; Design - B.S., M.A.D.; Supervision - E.D., N.B.; Data Collection and/or Processing - M.A.D.,
B.S.; Analysis and/or Interpretation - M.A.D., B.S.; Literature Search M.A.D., B.S.; Writing Manuscript - M.A.D., B.S.; Critical Review - E.D., N.B.

Conflict of Interest: The authors have no conflicts of interest to declare.

Financial Disclosure: The authors declared that this study has received no financial support.

\section{REFERENCES}

I. Sreenivasan P, Purushothaman KK. Radiological clue to diagnosis of Canavan disease. Indian J Pediatr. 2013;80(I):75-77. [CrossRef]

2. Lyon G, Fattal-Valevski A, Kolodny EH. Leukodystrophies: Clinical and genetic aspects. Top Magn Reson Imaging. 2006;17(4):219-242. [CrossRef]

3. Wijayasinghe YS, Pavlovsky AG, Viola RE. Aspartoacylase catalytic deficiency as the cause of Canavan disease: A structural perspective. Biochemistry. 2014;53(30):4970-4978. [CrossRef]

4. Baslow MH, Guilfoyle DN. Canavan disease, a rare earlyonset human spongiform leukodystrophy: Insights into its genesis and possible clinical interventions. Biochimie. 2013;95(4):946-956. [CrossRef]

5. Pleasure D, Guo F, Chechneva O, et al. Pathophysiology and treatment of Canavan disease. Neurochem Res. 2020;45(3):561-565. [CrossRef]

6. Bokhari MR, Samanta D, Bokhari SRA. Canavan disease. In StatPearls. Treasure Island, FL: StatPearls Publishing, 2021.

7. Di Pietro V, Cavallari U, Amorini AM, et al. New T530C mutation in the aspartoacylase gene caused Canavan disease with no correlation between severity and $\mathrm{N}$-acetylaspartate excretion. Clin Biochem. 2013;46(18):1092-1094.

8. Baslow MH, Hrabe J, Guilfoyle DN. Dynamic relationship between neurostimulation and $\mathrm{N}$-acetylaspartate metabolism in the human visual cortex: Evidence that NAA functions as a molecular water pump during visual stimulation. J Mol Neurosci. 2007;32:235-245. [CrossRef]

9. Hoshino $\mathrm{H}$, Kubot M. Canavan disease: Clinical features and recent advances in research. Pediatr Int. 2014;56:477-483. [CrossRef]

I0. Hagenfeldt L, Bollgren I, Venizelos N. N-Acetylaspartic aciduria due to aspartoacylase deficiency: A new aetiology of childhood leukodystrophy. J Inherit Metab Dis. 1987;10:135-14I. [Database] [CrossRef]

II. Bluml S. in vivo quantitation of cerebral metabolite concentrations using natural abundance I3C MRS at 1.5 T. J Magn Reson. 1999;136:219-225. [CrossRef]

12. Kumar S, Mattan NS, de Vellis J. Canavan disease: A white matter disorder. Ment Retard Dev Disabil Res Rev. 2006;12:157-165. [CrossRef]

13. Madhavarao CN, Arun P, Moffett JR, et al. Defective Nacetylaspartate catabolism reduces brain acetate levels and myelin lipid synthesis in Canavan's disease. Proc Natl Acad Sci USA. 2005;102:522I-5226. [CrossRef]

14. Wang J, Leone $P, W \cup G$, et al. Myelin lipid abnormalities in the aspartoacylase-deficient tremor rat. Neurochem Res. 2009;34:138148. [CrossRef]

15. Baslow $\mathrm{MH}$. Brain $\mathrm{N}$-acetylaspartate as a molecular water pump and its role in the etiology of Canavan disease: A mechanistic explanation. J Mol Neurosci. 2003;21:185-190. [CrossRef]

16. Tranberg $M$, Stridh $M H$, Guy $Y$, et al. NMDA-receptor mediated efflux of $\mathrm{N}$-acetylaspartate: Physiological and/or pathological importance? Neurochem Int. 2004;45:1195-1204. [CrossRef]

17. Klugmann M, Leichtlein CB, Symes CW, Serikawa T, Young D, During MJ. Restoration of aspartoacylase activity in CNS neurons does not ameliorate motor deficits and demyelination in a model 
of Canavan disease. Mol Ther. 2005;Il:745-753. [1585I0I3] [CrossRef]

18. Nagelhus EA, Mathiisen TM, Ottersen OP. Aquaporin-4 in the central nervous system: Cellular and subcellular distribution and coexpression with KIR4.I. Neuroscience. 2004;129(4):905-913. [CrossRef]

19. Masaki H, Wakayama Y, Hara H, et al. Immunocytochemical studies of aquaporin 4, Kir4.l, and alphal-syntrophin in the astrocyte endfeet of mouse brain capillaries. Acta Histochem Cytochem. 2010;43(4):99-105. [CrossRef]

20. Clarner T, Wieczorek N, Krauspe B, Jansen K, Beyer C, Kipp M. Astroglial redistribution of aquaporin 4 during spongy degeneration in a Canavan disease mouse model. J Mol Neurosci. 2014;53:22-30. [CrossRef]

21. Francis JS, Strande L, Markov V, Leone P. Aspartoacylase supports oxidative energy metabolism during myelination. J Cereb Blood Flow Metab. 2012;32:1725-1736. [CrossRef]

22. Liu J, Casaccia P. Epigenetic regulation of oligodendrocyte identity. Trends Neurosci. 2010;33:193-20I. [CrossRef]

23. Bhakoo KK, Pearce D. In vitro expression of $\mathrm{N}$-acetyl aspartate by oligodendrocytes: Implications for proton magnetic resonance spectroscopy signal in vivo. J Neurochem. 200l;74:254-262. [CrossRef]

24. Mattan NS, Ghiani CA, Lloyd M, et al. Aspartoacylase deficiency affects early postnatal development of oligodendrocytes and myelination. Neurobiol Dis. 2010;40:432-443. [CrossRef]

25. Kolodziejczyk K, Hamilton NB, Wade A, Karadottir R, Attwell D. The effect of $\mathrm{N}$-acetyl-aspartyl-glutamate and $\mathrm{N}$-acetyl-aspartate on white matter oligodendrocytes. Brain. 2009;|32:|1496-1508. [CrossRef]

26. Traeger EC, Rapin I. The clinical course of Canavan disease. Pediatr Neurol. 1998;18:207-212. [CrossRef]

27. Surendran S, Michals-Matalon K, Quast MJ, et al. Canavan disease: A monogenic trait with complex genomic interaction. Mol Genet Metab. 2003;80:74-80. [CrossRef]

28. Matalon R, Delgado L, Michals-Matalon K. Canavan disease. In Adam MP, Ardinger HH, Pagon RA, Wallace SE, Bean LJH, Mirzaa Amemiya A (eds.): GeneReviews. Seattle, WA: University of Washington, 1993-2021.

29. Janson CG, Kolodny EH, Zeng BJ, et al. Mild-onset presentation of Canavan's disease associated with novel G2I2A point mutation in aspartoacylase gene. Ann Neurol. 2006;59:428-43I. [CrossRef]

30. Velinov M, Zellers N, Styles J, Wisniewski K. Homozygosity for mutation G212A of the gene for aspartoacylase is associated with atypical form of Canavan's disease. Clin Genet. 2007;73:288-289. [CrossRef]

31. Dirik M, Sanlidag B, Bulakbası N, Serakinci N, Dirik E. Canavan disease: First normocephalic case from North Cyprus. Cyprus J Med Sci. 2018;|:33-35.

32. Gowda VK, Bhat MD, Srinivasan VM, Prasad C, Benakappa A, Faruq M. A case of Canavan disease with microcephaly. Brain Dev. 2016;38(8):759-762. [CrossRef]

33. Bokhari MR, Samanta D, Bokhari SRA. Canavan Disease. Treasure Island, FL: StatPearls Publishing, 2017.

34. Matalon R, Michals-Matalon K. Canavan disease synonyms: ASPA deficiency, aspartoacylase deficiency. In Adam MP, Ardinger HH, Pagon RA, et al. (eds.): Gene Reviews. Seattle, WA: University of Washington, 1993-2017.

35. Benson MD, Plemel DJA, Freund PR, et al. Severe retinal degeneration in a patient with canavan disease. Ophthalmic Genet. 2021;42(I):75-78. [CrossRef]

36. Matalon R, Kaul R, Casanova J, et al. Aspartoacylase deficiency: The enzyme defect in canavan disease. J Inherit Metab Dis. 1989;12(2):329-331. [CrossRef]
37. Karımzadeh $\mathrm{P}$, Jafari $\mathrm{N}$, Biglari $\mathrm{HN}$, et al. The clinical features and diagnosis of canavan's disease: A case series of Iranian patients. Iran J Child Neurol. 2014;8(4):66-71.

38. Matalon R, Michals K, Sebesta D, Deanching M, Gashkoff P, Casanova J. Aspartoacylase deficiency and $\mathrm{N}$-acetylaspartic aciduria in patients with Canavan disease. Am J Med Genet. 1988;29:46347l. [CrossRef]

39. Bennett MJ, Gibson KM, Sherwood WG, et al. Reliable prenatal diagnosis of canavan disease (aspartoacylase deficiency): Comparison of enzymatic and metabolite analysis. J Inherit Metab Dis. 1993;16:831-836. [CrossRef]

40. Cecil KM, Kos RS. Magnetic resonance spectroscopy and metabolic imaging in white matter diseases and pediatric disorders. Top Magn Reson Imaging. 2006;17:275-293. [CrossRef]

4l. Janson CG, McPhee SW, Francis J, et al. Natural history of canavan disease revealed by proton magnetic resonance spectroscopy (IH-MRS) and diffusion-weighted MRI. Neuropediatrics. 2006;37:209-221. [CrossRef]

42. Oksuler YF, Cakmakcı H, Kurul S, Oksuzler M, Dirik E. Diagnostic value of diffusion-weighted magnetic resonance imaging in pediatric cerebral diseases. Pediatr Neurol. 2005;32:325-333. [CrossRef]

43. Israni AV, Mandal A. Canavan disease with typical brain MRI and MRS findings. Neurol India. 2017;65(5):|191-||92. [CrossRef]

44. Pradhan S, Goyal G. Teaching Neurolmages: Honeycomb appearance of the brain in a patient with canavan disease. Neurology. 2011;76(I3):e68. [CrossRef]

45. Merrill ST, Nelson GR, Longo N, Bonkowsky JL. Cytotoxic edema and diffusion restriction as an early pathoradiologic marker in Canavan disease: Case report and review of the literature. Orphanet J Rare Dis. 2016;II(I):169. [CrossRef]

46. Kamate $M$, Kabate $V$, Malhotra $M$. Spongy white matter: A novel neuroimaging finding in canavan disease. Pediatr Neurol. 2016;56:92-93. [CrossRef]

47. Surendran S, Bamforth FJ, Chan A, Tyring SK, Goodman SI, MataIon R. Mild elevation of $\mathrm{N}$-acetylaspartic acid and macrocephaly: Diagnostic problem. J Child Neurol. 2003;18:809-812. [CrossRef]

48. Yalcinkaya C, Benbir G, Salomons GS, Karaarslan E, et al. Atypical MRI findings in Canavan disease: A patient with a mild course. Neuropediatrics. 2005;36:336-339. [CrossRef]

49. Jauhari P, Saini L, Chakrabarty B, Kumar A, Gulati S. Juvenile Canavan disease: A leukodystrophy without white matter changes. Neuropediatrics. 2018;49(6):420-42I. [CrossRef]

50. Çakar NE, Aksu Uzunhan TA. Case of juvenile Canavan disease with distinct pons involvement. Brain Dev. 2020;42(2):222-225. [CrossRef]

51. Nguyen HV, Ishak GE. Canavan disease-Unusual imaging features in a child with mild clinical presentation. Pediatr Radiol. 2015;45(3):457-460. [CrossRef]

52. Michals K, Matalon R. Canavan disease. In Raymond GV, Eichler F, Fatemi A, Naidu S (eds.): Leukodystrophies. London: Mac Keith Press, 2011:156-169.

53. Gujar SK, Maheshwari S, Bjorkman-Burtscher I, Sundgren PC. Magnetic resonance spectroscopy. J Neuroophthalmol. 2005;25:217-226. [CrossRef]

54. Kaul R, Casanova J, Johnson AB, Tang P, Matalon R. Purification, characterization, and localization of aspartoacylase from bovine brain. J Neurochem. 1991;56:129-135. [CrossRef]

55. Sistermans EA, de Coo RFM, van Beerendonk HM, et al. Mutation detection in the aspartoacylase gene in 17 patients with Canavan disease: Four new mutations in the non-Jewish population. Eur $J$ Hum Genet. 2000;8:557-560. [CrossRef]

56. Tacke U, Olbrich H, Sass JO, et al. Possible genotype-phenotype correlations in children with mild clinical course of Canavan disease. Neuropediatrics. 2005;36:252-255. [CrossRef] 
57. Mendes MI, Smith DE, Pop A, et al. Clinically distinct phenotypes of Canavan disease correlate with residual aspartoacylase enzyme activity. Hum Mutat. 2017;38(5):524-531. [CrossRef]

58. ACOG Committee on Genetics. ACOG committee opinion. Number 442, October. Prenatal and preconceptional carrier screening for genetic diseases in individuals of Eastern European Jewish descent. Obstet Gynecol. 2009;|l4:950-953. [CrossRef]

59. Matalon RM, Michals-Matalon K. Spongy degeneration of the brain, Canavan disease: Biochemical and molecular findings. Front Biosci. 2000;5:D307-D3II.

60. Janson CG, Assadi M, Francis J, Bilaniuk L, Shera D, Leone P. Lithium citrate for Canavan disease. Pediatr Neurol. 2005;33:235-243. [CrossRef]

61. Assadi M, Janson C, Wang DJ, et al. Lithium citrate reduces excessive intra-cerebral $\mathrm{N}$-acetyl aspartate in Canavan disease. Eur J Paediatr Neurol. 20I0;14:354-359. [CrossRef]

62. Arun P, Madhavarao CN, Moffett JR, et al. Metabolic acetate therapy improves phenotype in the tremor rat model of Canavan disease. J Inherit Metab Dis. 2010;33:195-210. [CrossRef]

63. Mathew R, Arun P, Madhavarao CN, Moffett JR, Namboodiri MA. Progress toward acetate supplementation therapy for Canavan disease: Glyceryl triacetate administration increases acetate, but not $\mathrm{N}$-acetylaspartate, levels in brain. J Pharmacol Exp Ther. 2005;315:297-303. [16002461] [CrossRef]

64. Topçu M, Yalnizoğlu D, Saatçi l, et al. Effect of topiramate on enlargement of head in Canavan disease: A new option for treatment of megalencephaly. Turk J Pediatr. 2004;46:67-71.

65. Roscoe RB, Elliott C, Zarros A, Baillie GS. Non-genetic therapeutic approaches to Canavan disease. J Neurol Sci. 2016;366:116-124. [CrossRef]

66. Feng L, Chao J, Tian E, et al. Cell-based therapy for Canavan disease using human iPSC-derived NPCs and OPCs. Adv Sci. 2020;7(23).
67. Starling S. White matter disease: Targeted aspartoacylase gene therapy reverts Canavan disease. Nat Rev Neurol. 2018;14(I):4. [CrossRef]

68. von Jonquieres G, Spencer ZHT, Rowlands BD, et al. Uncoupling Nacetylaspartate from brain pathology: Implications for Canavan disease gene therapy. Acta Neuropathol. 2018;135(I):95-II3. [CrossRef]

69. Ahmed SS, Li H, Cao $C$, et al. A single intravenous rAAV injection as late as P20 achieves efficacious and sustained CNS gene therapy in Canavan mice. Mol Ther. 2013;21:2136-2147. [CrossRef]

70. McPhee SW, Francis J, Janson CG, et al. Effects of AAV-2-mediated aspartoacylase gene transfer in the tremor rat model of Canavan disease. Brain Res Mol Brain Res. 2005;|35:|I2-I2I. [CrossRef]

71. Leone P, Shera D, McPhee SW, et al. Long-term follow-up after gene therapy for Canavan disease. Sci Trans/ Med. 2012;4:165ral63. [CrossRef]

72. Leone $\mathrm{P}$, Janson CG, Bilaniuk L, et al. Aspartoacylase gene transfer to the mammalian central nervous system with therapeutic implications for Canavan disease. Ann Neurol. 2000;48:27-38. [CrossRef]

73. Gessler DJ, Li D, Xu H, et al. Redirecting N-acetylaspartate metabolism in the central nervous system normalizes myelination and rescues Canavan disease. JCl Insight. 2017;2:e90807. [CrossRef]

74. Baslow MH. Rescuing Canavan disease: Engineering the wrong cell at the right time. J Inherit Metab Dis. 2017;40(5):627-628. [CrossRef]

75. Mendell JR, Al-Zaidy SA, Rodino-Klapac LR, et al. Current clinical applications of in vivo gene therapy with AAVs. Mol Ther. 2021;29(2):464-488. [CrossRef]

76. Perez BA, Shutterly A, Chan YK, Byrne BJ, Corti M. Management of neuroinflammatory responses to $A A V$-mediated gene therapies for neurodegenerative diseases. Brain Sci. 2020;I0(2):I19. [CrossRef] 